\title{
Penerima Sinyal Emergency Locator Transmitter dengan Metode Direct Receiver pada Frekuensi
}

\author{
$121,5 \mathrm{MHz}$ \\ Rustamaji $^{1}$, Kania Sawitri ${ }^{2}$, dan Arief Shubhan Hakim ${ }^{3}$ \\ Jurusan Teknik Elektro, Institut Teknologi Nasional Bandung \\ Jl. P.H.H. Mustofa No. 23, Bandung, 40124, Indonesia \\ rustamajisaja@gmail.com ${ }^{1}$, kania@itenas.ac.id ${ }^{2}$, ariefshubhan@gmail.com ${ }^{3}$
}

\begin{abstract}
To find out the location of an aircraft accident from an ELT signal beam of $121.5 \mathrm{MHz}$, search and rescue (SAR) officers or civil aviation authorities need an ELT signal receiver device that works at the same frequency, which is $121.5 \mathrm{MHz}$. The purpose of this research is to produce an ELT signal receiver with direct receiver method at a frequency of $121.5 \mathrm{MHz}$ which is simpler, requires fewer RF devices, and is according to specifications for civil aviation. In this research, the design and realization of ELT signal receivers are carried out using the direct receiver method, including: $a$ BPF and a RF amplifier as a direct receiver circuit, an $A M$ demodulator, and an audio amplifier. Based on the results of measurements and tests that have been done, the direct receiver circuit can receive an ELT signal at a frequency of $121.5 \mathrm{MHz}$ in the range of 121.330 to $121.617 \mathrm{MHz}$ with $-40.35 \mathrm{~dB}$ sensitivity, the AM demodulator can demodulate the audio signal at a frequency of $346.6 \mathrm{~Hz}$, and the audio signal at a frequency of $337.6 \mathrm{~Hz}$ as a pointer to an ELT signal can be heard through the loudspeaker. The results of this study are ELT signal receivers with direct receiver method at a frequency of $121.5 \mathrm{MHz}$ which are according to specifications for civil aviation.
\end{abstract}

Keywords- ELT signal, 121.5 MHzfrequency, direct receiver, audio signal, ELT signal receiver

\begin{abstract}
Abstrak- Untuk mengetahui lokasi terjadinya kecelakaan pesawat terbang dari adanya pancaran sinyal emergency locator transmitter (ELT) sebesar 121,5 $\mathrm{MHz}$, petugas search and rescue (SAR) atau otoritas penerbangan sipil memerlukan perangkat penerima sinyal ELT yang bekerja pada frekuensi sama, yaitu sebesar 121,5 MHz. Tujuan dari penelitian ini untuk menghasilkan penerima sinyal ELT dengan metode direct receiver pada frekuensi $121,5 \mathrm{MHz}$ yang lebih sederhana, dan membutuhkan lebih sedikit divais RF, serta sesuai spesifikasi untuk penerbangan sipil. Pada penelitian ini dilakukan perancangan dan realisasi penerima sinyal ELT dengan metode direct receiver, meliputi: band pass filter (BPF) dan penguat radio frequency (RF) sebagai rangkaian direct receiver, demodulator amplitude modulation (AM), dan penguat audio. Berdasarkan hasil pengukuran dan pengujian yang telah dilakukan, rangkaian direct receiver dapat menerima sinyal ELT pada frekuensi 121,5 MHz dalam rentang 121,330 s.d 121,617 MHz dengan sensitifitas -40,35 dB, demodulator AM dapat mendemodulasi sinyal audio pada frekuensi $346,6 \mathrm{~Hz}$, dan sinyal audio pada frekuensi $337,6 \mathrm{~Hz}$ sebagai penunjuk adan ya sinyal ELT dapat didengar melalui loudspeaker. Hasil penelitian ini adalah penerima sinyal ELT dengan metode direct receiver pada frekuensi $121,5 \mathrm{MHz}$ yang sesuai spesifikasi untuk penerbangan sipil.
\end{abstract}

Kata kunci-Sinyal ELT, frekuensi 121,5 MHz, direct receiver, sinyal audio, penerima sinyal ELT

\section{PENDAhUluan}

Kecelakaan pesawat terbang dalam fase penerbangan, karena faktor cuaca ataupun kondisi pesawat terbang bisa terjadi dimanapun baik di atas daratan maupun lautan. Salah satu cara untuk menunjukkan posisi pesawat terbang yang mengalami crashed, yaitu dengan menempatkan emergency locator transmitter (ELT) di badan pesawat terbang. ELT berupa transmitter dengan daya pancar rendah dan dilengkapi antena, telah digunakan secara luas untuk penerbangan pada frekuensi 121,5 $\mathrm{MHz}$ (sipil) dan $243 \mathrm{MHz}$ (militer) [1]. Apabila terjadi kecelakaan pada pesawat terbang dan ELT mengalami hempasan atau benturan yang cukup keras, maka secara otomatis akan memancarkan sinyal pada frekuensi tertentu sebesar 121,5 atau $243 \mathrm{MHz}$ secara terus-menerus sebagai beacon untuk memberitahukan lokasi atau posisi diri [2].

Untuk mengetahui lokasi kecelakaan pesawat terbang dari adanya pancaran sinyal ELT, petugas search and rescue (SAR) atau otoritas penerbangan memerlukan perangkat penerima sinyal ELT yang bekerja pada frekuensi sama, yaitu 121,5 $\mathrm{MHz}$ [3], atau dengan cara lain petugas SAR melakukan pencarian lokasi kecelakaan pesawat terbang menggunakan metode kerjasama antara dua autonomous unmanned aerial vehicles (UAV) [4]. Karena pentingnya, hingga saat ini teknologi ELT terus diteliti dan dikembangkan, beberapa 
masalah yang dihadapi berupa aktivasi baterai pada desain perangkat emergency homing berbas is pesawat saat ini seperti emergency locator beacon (ELB) dan underwater locator beacon (ULB) [5], dan pengembangan sistem ELT ekonomis otomatis yang ditempatkan pada pesawat terbang [6], dan konsep desain electronic position indicating radio beacon (EIRB) yang dapat terlontar secara otomatis dari pesawat terbang yang mengalami kecelakaan di laut [7].

Beberapa penelitian yang membahas tentang pengembangan dan aplikasi penerima ELT, antara lain: aplikasi masa depan arsitektur direct $R F$ sampling (DRFS) pada perangkat ELT [8], ujicoba deteksi distress beacon UHF signal yang terpancar dari lokasi kecelakaan pesawat terbang oleh petugas SAR menggunakan Cospas-Sarsat System [9], penjejakan pesawat terbang yang mengalami kecelakaan menggunakan ELT berbasis Cospas-Sarsat System [10], dan desain web based module untuk SAR pada ELT receiver dengan sistem Cospas-Sarsat [11]. Selain itu, terdapat pula penelitian yang membahas penerima ELT pada frekuensi 406 $\mathrm{MHz}$, diantaranya: desain dan realisasi ELT beacon dan decoder pada frekuensi $406 \mathrm{MHz}$ [12], desain decoder mobile untuk distress beacon $406 \mathrm{MHz}$ [13], pengembangan emergency radio beacon $406 \mathrm{MHz}$ yang didesain khusus untuk menemukan lokasi small unmanned aerial vehicle (UAV) [14], dan pengembangan GPS transceiver sebagai emergency locator beacon untuk dipasang pada quadcopter [15]. Sedangkan penelitian yang me mbahas tentang pencarian pesawat terbang, diantaranya: desain algoritma pengolahan data acoustic locator (AL) pasif untuk deteksi dan pencarian pesawat terbang [16], teknik passive location (PL) yang dipasang pada maritime patrol aircraft (MPA) untuk pencarian pesawat terbang [17], dan metode penentuan posisi pesawat terbang dengan menggunakan synthetic aperture radars (SARs) [18].

Dikarenakan kerumitan teknologi penerima sinyal ELT yang digunakan pada penelitian lain, seperti: arsitektur DRFS [8], web based module [11], dengan GPS [15], algoritma AL pasif [16], teknik PL [17], dan metode SARs [18]; penerima yang berbasis satelit Cospas-Sarsat [9]-[11]; penerima yang dipasang pada quadcopter, pesawat terbang, atau MPA [15][18]; penerima berbasis pada frekuensi kerja $406 \mathrm{MHz}$ [12][14]; dan pentingnya kegunaan perangkat penerima sinyal ELT untuk menangkap dan mendeteksi pancaran sinyal ELT sebagai kelanjutan dari hasil penelitian [2] dan [19], serta untuk mendukung kemandirian dan penguasaan teknologi perangkat penerima sinyal ELT menjadi dasar penelitian ini dilakukan. Metode penerimaan sinyal ELT pada penelitian [9]-[18] berbasis "super heterodyning", sedangkan metode yang digunakan pada penelitian ini adalah "direct receiver", karena lebih sederhana dan secara signifikan akan mengurangi divais radio frequency (RF) yang digunakan seperti dipaparkan pada [8].

Tujuan penelitian ini untuk menghasilkan penerima sinyal ELT dengan metode direct receiver pada frekuensi 121,5 $\mathrm{MHz}$, terdiri dari: band pass filter (BPF) dan penguat radio frequency (RF) sebagai rangkaian direct receiver, demodulator AM, dan penguat audio. Rangkaian ini lebih sederhana, membutuhkan lebih sedikit divais RF, menggunakan sumber tenaga dari baterai, dan dapat dijinjing atau portable. Dipilih frekuensi $121,5 \mathrm{MHz}$ karena mempunyai jangkauan lebih jauh tanpa line of sight (LoS) yang clear seperti dinyatakan pada [9] dan sesuai spesifikasi penerbangan sipil [1]. Lebih lanjut hasil penelitian ini dapat digunakan untuk pengembangan pemancar dan penerima sinyal ELT, serta dapat juga diimplementasikan pada sistem pencari (locator) pesawat terbang dengan menambahkan perangkat radio direction finder (RDF) [20].

\section{METODE}

Hubungan antara transmitter ELT di pesawat terbang yang crashed, yang berfungsi memancarkan sinyal ELT; dengan penerima sinyal ELT di petugas SAR [3], yang berfungsi menangkap sinyal ELT, seperti ditunjukkan pada Gambar 1 .

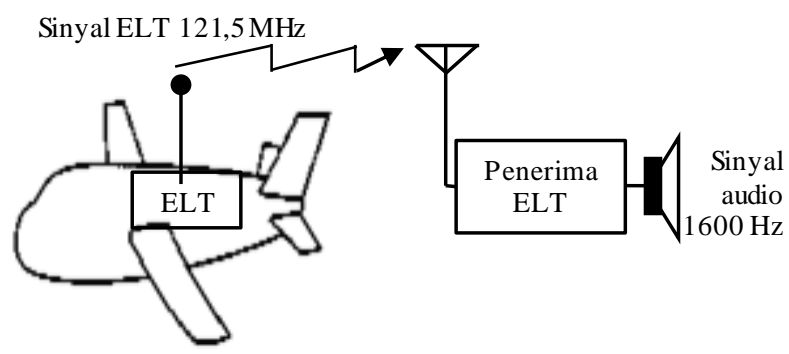

Gambar 1. Hubungan antara transmitter ELT di pesawat yang crashed, dengan penerima ELT di petugas SAR

Dari Gambar 1, transmitter ELT di pesawat terbang yang crashed, memancarkan sinyal ELT pada fre kuensi $121,5 \mathrm{MHz}$ yang termodulasi AM oleh sinyal audio sinusoida $1600 \mathrm{~Hz}$. Penerima sinyal ELT akan menangkap sinyal ELT dan mendemodulasi atau mengambil kembali sinyal audio sinusoida $1600 \mathrm{~Hz}$ dan ditampilkan atau didengar suaranya, untuk menunjukkan adanya sinyal ELT. Penerima sinyal ELT juga dapat dipadukan dengan perangkat RDF sehingga dapat diketahui lokasi dan arah pancaran sinyal ELT [20].

Penerima ELT dirancang untuk dapat menerima sinyal ELT pada frekuensi $121,5 \mathrm{MHz}$ yang dipancarkan oleh transmitter ELT dengan spesifikasi sesuai penerbangan sipil, berupa: sinyal amplitude modulation (AM) pada frekuensi $(121,5 \mathrm{MHz} \pm 6 \mathrm{kHz})$ atau 121,494 s.d $121,506 \mathrm{MHz}$ termodulasi oleh sinyal audio sinusoida pada range tidak kurang dari $700 \mathrm{~Hz}$ di dalam band 300 s.d $1600 \mathrm{~Hz}$, pada laju pengulangan sweep antara 2 s.d $4 \mathrm{~Hz}$, seperti ditunjukkan pada Gambar 2.

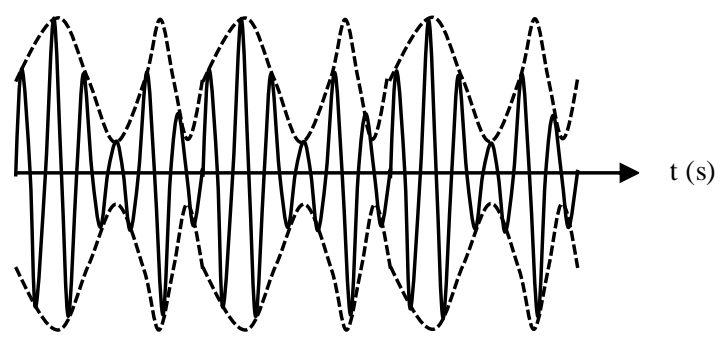

Gambar 2. Sinyal ELT [2] 
Metode yang digunakan pada penelitian ini adalah perancangan, realisasi, serta pengukuran dan pengujian penerima sinyal ELT, untuk menghasilkan "Penerima sinyal ELT dengan metode direct receiver yang mampu bekerja pada frekuensi 121,5 MHz". Rangkaian "Penerima sinyal ELT dengan metode direct receiver" ini, terdiri dari: BPF dan penguat RF sebagai rangkaian direct receiver, demodulator $\mathrm{AM}$, dan penguat audio; serta menggunakan IC dan divais analog yang tersedia bebas di pasaran. Diagram blok penerima sinyal ELT dengan metode direct receiver, seperti ditunjukkan pada Gambar 3.

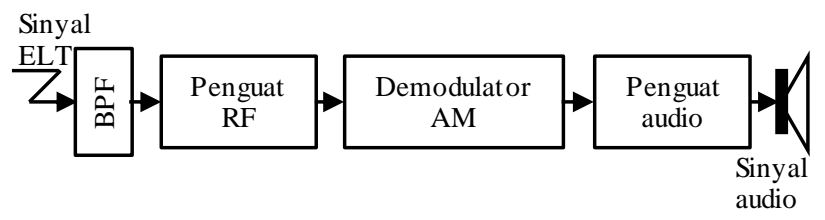

Gambar 3. Diagram blok penerima sinyal ELT dengan metode direct receiver

Dari Gambar 3, penerima sinyal ELT dengan metode direct receiver pada frekuensi $121,5 \mathrm{MHz}$ terdiri dari: $\mathrm{BPF}$ dan penguat $\mathrm{RF}$ berfungsi sebagai direct receiver untuk menerima, memilah, dan memperkuat sinyal ELT pada frekuensi 121,5 MHz; demodulator AM berfungsi untuk mendemodulasi sinyal informasi berupa audio sinusoida 1600 $\mathrm{Hz}$ yang dibawa oleh sinyal ELT; penguat audio berfungsi untuk memperkuat level tegangan sinyal audio sinusoida, yang akan didengar suaranya melalui loudspeaker. Rangkaian lengkap penerima sinyal ELT dengan metode direct receiver pada frekuensi 121,5 MHz, seperti ditunjukkan pada Gambar 4, dengan spesifikasi yang direncanakan, yaitu: bekerja pada rentang frekuensi 121,494 s.d 121,506 MHz, penerimaan sinyal dengan metode direct receiver, jenis demodulasinya adalah AM, dan sinyal audio didengar suaranya melalui loudspeaker.

\section{A. Band Pass Filter (BPF)}

Rangkaian BPF terdiri dari susunan high pass filter (HPF) berupa kapasitor $C_{1}$ dan induktor $L_{1}$ seri, dan low pass filter (LPF) berupa kapasitor $C_{2}$ dan induktor $L_{2}$ paralel. BPF mempunyai frekuensi cut-off bawah $\left(f_{L}\right)$ dan frekuensi cutoff atas $\left(f_{H}\right)$, sesuai[21]:

$$
f_{L}=\frac{1}{2 \pi \cdot \sqrt{C_{2} \cdot L_{2}}} \mathrm{~Hz}
$$

dan

$$
f_{H}=\frac{1}{2 \pi \cdot \sqrt{C_{1} \cdot L_{1}}} \quad \mathrm{~Hz}
$$

Untuk meloloskan sinyal ELT pada frekuensi $121,5 \mathrm{MHz}$ $\pm 6 \mathrm{kHz}$, BPF dirancang pada frekuensi tengah $121,5 \mathrm{MHz}$ dan bandwidth $30 \mathrm{kHz}$, sehingga besarnya frekuensi cut-off bawah $f_{L}=(121,5 \mathrm{MHz}-15 \mathrm{kHz})=121,485 \mathrm{MHz}$, dan frekuensi cut-off atas $f_{H}=(121,5 \mathrm{MHz}+15 \mathrm{kHz})=121,515$ MHz. Karena $f_{L}=121,485 \mathrm{MHz}$ dan dipilih $L_{2}=1 \mu \mathrm{H}$, maka diperoleh $\mathrm{C}_{2}$ :

$$
C_{2}=\frac{1}{\left(2 \pi \cdot f_{L}\right)^{2} \cdot L_{2}}=1,716306 \mathrm{pF}
$$

Karena $f_{H}=121,515 \mathrm{MHz}$ dan dipilih $L_{1}=1 \mu \mathrm{H}$, maka diperoleh $C_{1}$ :

$$
C_{1}=\frac{1}{\left(2 \pi \cdot f_{H}\right)^{2} \cdot L_{1}}=1,715459 \mathrm{pF}
$$

sehingga divais yang dipasang, adalah: $L_{1}=L_{2}=1 \mu \mathrm{H}, C_{1}=1,7$ $\mathrm{pF}$, dan $C_{2}=1,8 \mathrm{pF}$.

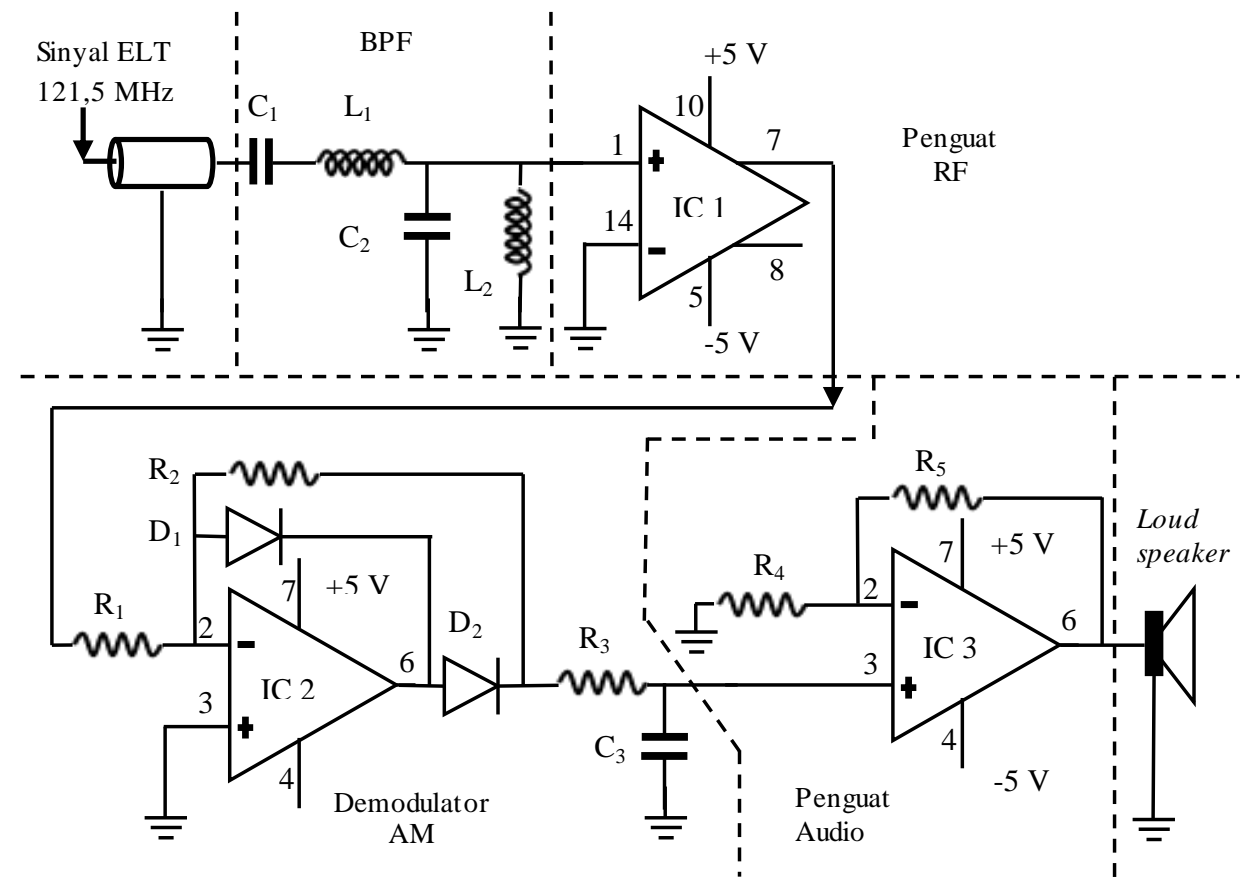

Gambar 4. Rangkaian lengkap penerima sinyal ELT dengan metode direct receiver pada frekuensi 121,5 MHz 


\section{B. Penguat Radio Frequency (RF)}

Rangkaian penguat RF (IC 1) berupa differential amplifier UA $733 \mathrm{CN}$ produk dari Texas Instruments Incorporated, dapat bekerja untuk memperkuat sinyal RF sebagai video amplifier hingga frekuensi $200 \mathrm{MHz}$. Penguat ini dengan mode differential amplifier dapat me mpunyai voltage gain antara 8 s.d 10 kali, sehingga cocok untuk memperkuat tegangan sinyal ELT pada frekuensi 121,5 MHz.

\section{Demodulator AM}

Demodulator AM yang digunakan berupa jenis detektor energi atau envelope detector, terdiri dari bagian penyearah setengah gelombang (half-wave rectifier) aktif dan perata (filter).

- Penyearah setengah gelombang berupa dioda germanium $D_{1}$ dan $D_{2}$, dengan inverting amplifier (IC 2) berupa opamp LM 741 produk dari National Semiconductor Corp dilengkapi resistor feedback $R_{1}$ dan $R_{2}$, mempunyai penguatan tegangan (inverting voltage gain) $A_{v}$ [22]:

$$
A_{v}=-\frac{R_{2}}{R_{1}}
$$

Karena diperlukan $A_{v}=-10$, dan dipilih $R_{2}=27 \mathrm{k} \Omega$; maka diperoleh $R_{1}=2,7 \mathrm{k} \Omega$. Sehingga divais yang dipasang adalah $R_{1}=2,7 \mathrm{k} \Omega$ dan $R_{2}=27 \mathrm{k} \Omega$.

- Perata berupa low pass filter (LPF) orde 1, dengan divais resistor $R_{3}$ dan kapasitor $C_{3}$, mempunyai frekuensi cutoff $\left(f_{c}\right)=1600 \mathrm{~Hz}$ sesuai dengan frekuensi tertinggi sinyal audio yang akan dipilah [22]:

$$
f_{c}=\frac{1}{2 \pi \cdot R_{3} \cdot C_{3}} \mathrm{~Hz}
$$

Karena LPF untuk memilah frekuensi sinyal audio dibawah $1600 \mathrm{~Hz}$ dari keluaran penyearah, dan dipilih $C_{3}=1 \mu \mathrm{F}$; maka diperoleh $R_{3}=99,4719 \Omega$. Sehingga divais yang dipasang adalah $C_{3}=1 \mu \mathrm{F}$ dan $R_{3}=100 \Omega$.

\section{Penguat Audio}

Rangkaian penguat audio (IC 3) berupa non-inverting amplifier menggunakan op-amp LM 741 produk dari National Semiconductor Corp yang dilengkapi resistor feedback $R_{4}$ dan $R_{5}$, mempunyai penguatan tegangan (non-inverting gain) $A_{v}$ [22]:

$$
A_{v}=\left(1+\frac{R_{5}}{R_{4}}\right)
$$

Karena diperlukan $A_{v}=10$, dan dipilih $R_{5}=10 \mathrm{k} \Omega$; maka diperoleh $R_{4}=1,11 \mathrm{k} \Omega$. Sehingga divais yang dipasang adalah $R_{4}=1,1 \mathrm{k} \Omega$ dan $R_{5}=10 \mathrm{k} \Omega$.

\section{E. Rangkaian Penerima Sinyal ELT}

Rangkaian penerima sinyal ELT secara keseluruhan dihasilkan dari gabungan BPF dan penguat RF sebagai rangkaian direct receiver, demodulator $\mathrm{AM}$, dan penguat audio. Diagram blok dan rangkaian dari penerima sinyal ELT seperti ditunjukkan pada Gambar 3 dan Gambar 4, sedangkan tata letak rangkaian dengan divais terpasang pada satu lembar printed circuit board (PCB) seperti ditunjukkan pada Gambar 5. Dari Gambar 5, tata letak rangkaian penerima sinyal ELT, terdiri dari: bagian BPF dan penguat RF (sebagai direct receiver), demodulator $\mathrm{AM}$, dan penguat audio.

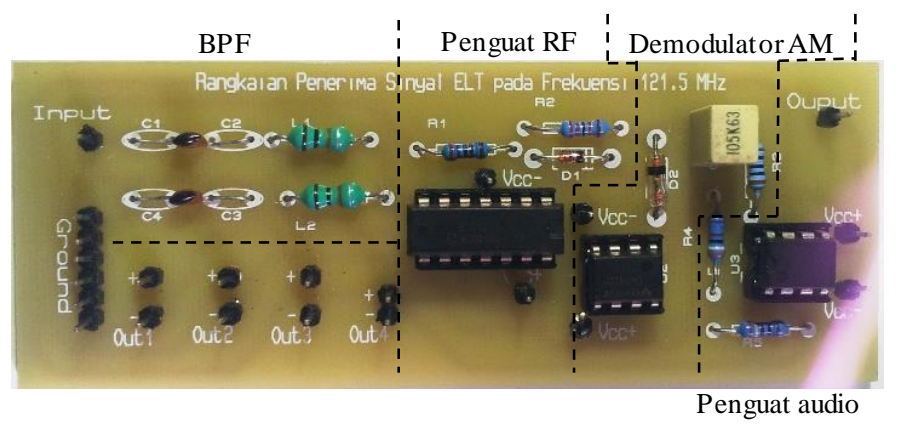

Gambar 5. Tata letak rangkaian dengan divais terpasang pada satu lembar PCB

\section{HASIL DAN PEMBAHASAN}

Dari hasil rancangan penerima sinyal ELT pada frekuensi $121,5 \mathrm{MHz}$, dilakukan pengukuran tiap bagian dan pengujian untuk menerima sinyal ELT pada frekuensi 121,5 MHz secara langsung melalui konektor BNC dari pembangkit sinyal ELT pada frekuensi 121,5 MHz hasil penelitian [2], pada pengujian ini tidak melibatkan dan memperhitungkan adanya noise atau interferensi dari sinyal lain. Diagram blok pengujian penerima sinyal ELT untuk menerima sinyal ELT pada frekuensi 121,5 $\mathrm{MHz}$, seperti ditunjukkan pada Gambar 6.

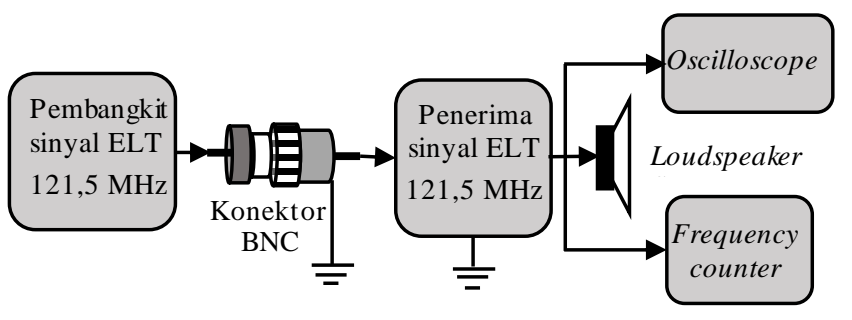

Gambar 6. Diagram blok pengujian penerima sinyal ELT untuk menerima sinyal ELT pada frekuensi $121,5 \mathrm{MHz}$

Dari Gambar 6, penerima sinyal ELT menerima sinyal ELT secara langsung dari pembangkit sinyal ELT pada frekuensi 121,5 MHz hasil penelitian [2] melalui konektor BNC. Gelombang sinyal ELT dari pembangkit sinyal ELT pada frekuensi 121,5 MHz, seperti ditunjukkan pada gambar 7 .

Gambar 7 (a), sinyal ELT berupa gelombang AM dengan tegangan $=392 \mathrm{mV}_{\mathrm{pp}}($ ditunjukkan panah a) dan frekuensi = $121,502 \mathrm{MHz}$ (ditunjukkan panah b) dimodulasi sinyal audio pada frekuensi $=300$ s.d $1600 \mathrm{~Hz}$, sedangkan Gambar 7 (b), menunjukkan frekuensi 121,5 MHz. Gelombang AM dengan tegangan peak $\left(V_{\text {peak }}\right)=390 \mathrm{mV}_{\mathrm{pp}}$ dan tegangan dip $\left(V_{\text {dip }}\right)=$ $240 \mathrm{mV}_{\mathrm{pp}}$, atau mempunyai indeks modulasi $\mathrm{m}(\%)=24,05 \%$. 


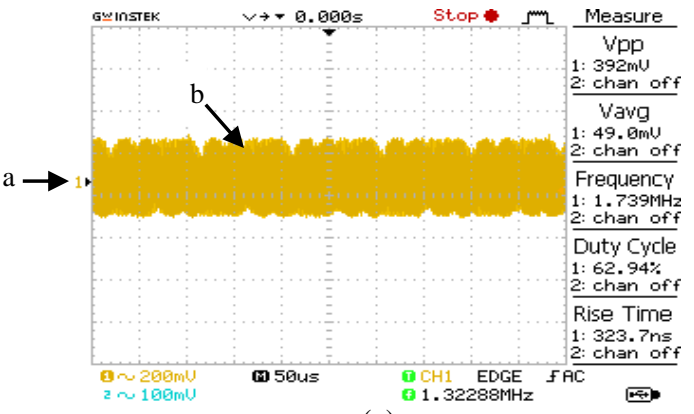

(a)

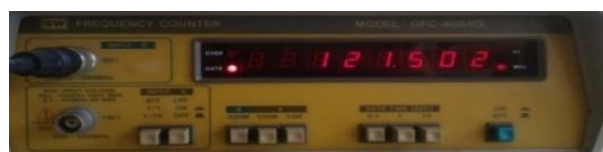

(b)

Gambar 7. (a) Gelombang dan (b) Frekuensi sinyal ELT dari pembangkit sinyal ELT pada frekuensi $121,5 \mathrm{MHz}$ [19]

\section{A. BPF dan Penguat RF}

$\mathrm{BPF}$ dan penguat $\mathrm{RF}$ sebagai direct receiver, untuk memilah dan memperkuat sinyal ELT pada frekuensi 121,5 $\mathrm{MHz} \pm 6 \mathrm{kHz}$. Hasil pengujian menunjukkan BPF dapat bekerja pada frekuensi antara 121,330 s.d 121,617 MHz atau mempunyai bandwidth $=287 \mathrm{kHz}$, dan penguat RF me mpunyai penguatan tegangan $=2,3$ s.d 2,8 kali. Ge lo mbang sinyal keluaran direct receiver seperti ditunjukkan pada Gambar 8.

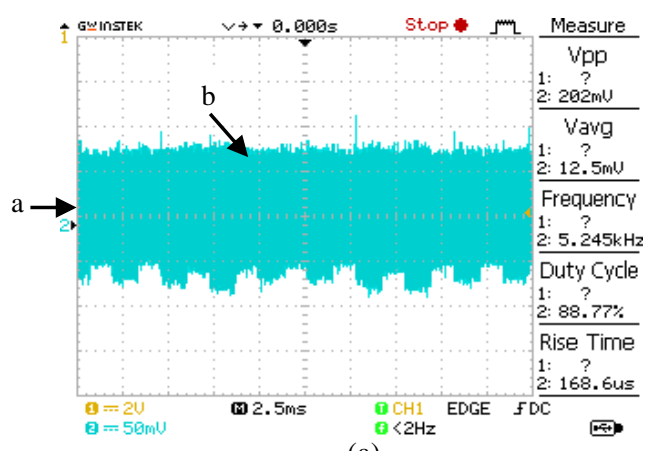

(a)

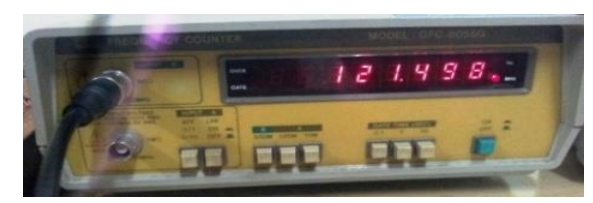

(b)

Gambar 8. (a) Gelombang dan (b) Frekuensi sinyal keluaran direct receiver

Gambar 8 (a), keluaran direct receiver berupa gelombang sinyal AM yang tidak simetris antara bagian positif dan bagian negatif, dengan tegangan $=202 \mathrm{mV}_{\mathrm{pp}}$ (ditunjukkan panah a) dan frekuensi sinyal $=121,498 \mathrm{MHz}$ (ditunjukkan panah b), sedangkan Gambar 8 (b) menunjukkan frekuensi 121,498 MHz. Hasil ini sesuai dengan yang direncanakan, bahwa direct receiver dapat menangkap sinyal ELT pada frekuensi $121,498 \mathrm{MHz}$, yang masih masuk dalam rentang frekuensi 121,494 s.d 121,506 MHz. Sensitifitas direct receiver dilihat dari level sinyal terkecil dari hasil pengujian, yang dapat ditangkap oleh penguat RF (UA $733 \mathrm{CN}$ ) adalah $19,2 \mathrm{mV}_{\mathrm{pp}}$ setara dengan $-40,35 \mathrm{~dB}$, dan selektifitas frekuensi antara 121,330 s.d 121,617 MHz.

\section{B. Demodulator AM}

Gelombang sinyal keluaran demodulator AM, seperti ditunjukkan pada Gambar 9. Gambar 9 (a), demodulator AM menghasilkan sinyal keluaran berupa gelombang mendekati bentuk persegi, dengan tegangan $=416 \mathrm{mV}_{\mathrm{pp}}$ (ditunjukkan panah a) dan frekuensi $=346,6 \mathrm{~Hz}$ (ditunjukkan panah b), sedangkan Gambar 9 (b) menunjukkan frekuensi 346,6 Hz. Hasil ini sudah sesuai dengan yang direncanakan, yaitu demodulator AM dapat mendemodulasi atau mengambil kembali sinyal audio pada frekuensi $=346,6 \mathrm{~Hz}$ dari sinyal ELT. Frekuensi ini masih masuk dalam rentang frekuensi sinyal audio 300 s.d $1600 \mathrm{~Hz}$.

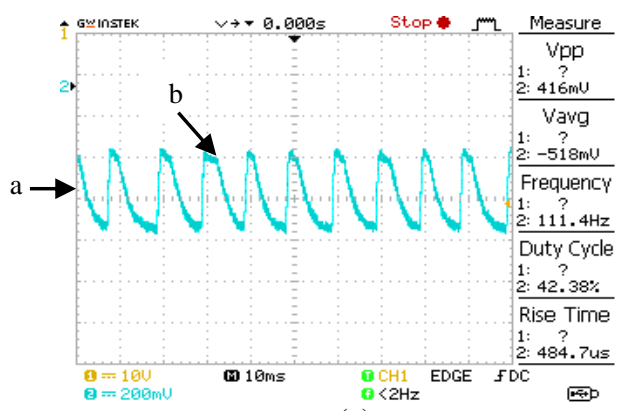

(a)

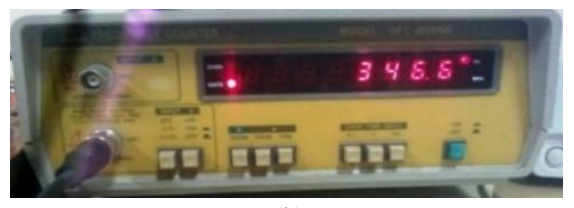

(b)

Gambar 9. (a) Gelombang dan (b) Frekuensi sinyal keluaran demodulator AM

\section{Penguat Audio}

Keluaran penguat audio sebagai keluaran penerima sinyal ELT dihubungkan ke loudspeaker untuk menampilkan suara audio hasil demodulasi, dan ke alat ukur berupa: oscilloscope dan frequency counter untuk mena mpilkan gambar gelo mbang sinyal audio. Gelombang sinyal keluaran penguat audio atau penerima sinyal ELT, seperti ditunjukkan pada Gambar 10.

Gambar 10 (a), penerima sinyal ELT dapat menghasilkan keluaran berupa gelo mbang sinyal audio pada tegangan $=3,07$ $\mathrm{V}_{\mathrm{pp}}$ (ditunjukkan panah a) dan frekuensi $=337,6 \mathrm{~Hz}$ (ditunjukkan panah b), sedangkan Gambar 10 (b) menunjukkan frekuensi $337,6 \mathrm{~Hz}$. Bentuk envelope gelombang yang belum rata, dikarenakan divais IC pada penguat RF mempunyai differential gain yang tidak seimbang. Hasil ini sudah sesuai dengan yang direncanakan, yaitu penerima sinyal ELT dapat menghasilkan kembali sinyal audio pada frekuensi $=337,6 \mathrm{~Hz}$ yang masih masuk dalam rentang 300 s.d $1600 \mathrm{~Hz}$, dan suara yang keluar melalui loudspeaker sebagai penunjuk adanya sinyal ELT, terdengar seperti suara audio aslinya yang dimodulasikan di pembangkit sinyal ELT pada frekuensi 121,5 MHz [2]. Hasil pengukuran dan pengujian penerima ELT untuk menerima sinyal ELT dari pembangkit sinyal ELT dirangkum pada Tabel I. 


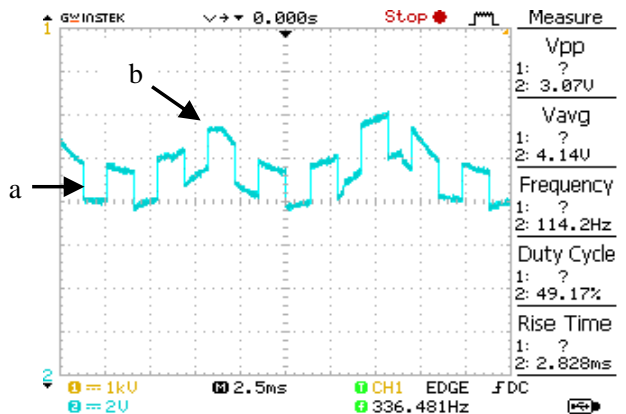

(a)

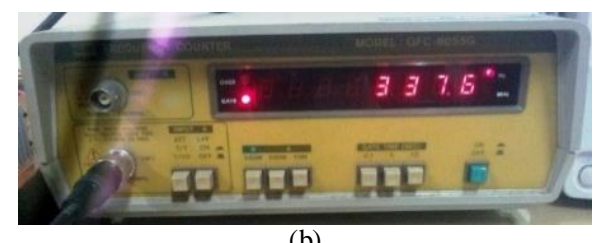

(b)

Gambar 10. (a) Gelombang dan (b) Frekuensi sinyal keluaran penerima sinyal ELT

TABEl I. HASIL PENGUKURAN DAN PENGUJIAN PENERIMA ELT

\begin{tabular}{|c|l|c|c|c|}
\hline \multirow{2}{*}{ No. } & \multirow{2}{*}{ Rangkaian } & \multicolumn{3}{|c|}{ Sinyal Keluaran } \\
\cline { 3 - 4 } & & \multicolumn{2}{|c|}{ Tegangan } & Frekuensi \\
\hline 1 & \multirow{2}{*}{$\begin{array}{l}\text { Direct } \\
\text { receiver }\end{array}$} & peak & dip & \multirow{2}{*}{$121,498 \mathrm{MHz}$} \\
\cline { 3 - 4 } 2 & $\begin{array}{l}\text { Demodulator } \\
\mathrm{AM}\end{array}$ & \multicolumn{2}{|c|}{$416 \mathrm{mV}_{\mathrm{pp}}$} & $346,6 \mathrm{~Hz}$ \\
\hline 3 & $\begin{array}{l}\text { Penguat } \\
\text { Audio }\end{array}$ & $3,07 \mathrm{~V}_{\mathrm{pp}}$ & $337,6 \mathrm{~Hz}$ \\
\hline
\end{tabular}

Dari Tabel I, pengukuran dan pengujian penerima sinyal ELT menunjukkan hasil sesuai yang diharapkan, yaitu: direct receiver mampu menerima frekuensi $121,498 \mathrm{MHz}$ yang masuk dalam rentang frekuensi 121,494 s.d 121,506 MHz, demodulator AM dapat mengambil kembali sinyal audio pada frekuensi 346,6 Hz yang masuk dalam rentang 300 s.d 1600 $\mathrm{Hz}$, dan penguat audio menghasilkan sinyal audio $337,6 \mathrm{~Hz}$ yang dapat didengar.

\section{Pembahasan}

Secara keseluruhan hasil perancangan dan realisasi, pengukuran serta pengujian sudah sesuai dengan yang direncanakan, yaitu penerima sinyal ELT dengan metode direct receiver berfungsi untuk menerima sinyal ELT pada frekuensi $121,498 \mathrm{MHz}$ yang masuk dalam rentang frekuensi 121,494 s.d 121,506 MHz, dan mengambil kembali sinyal audio pada frekuensi $337,6 \mathrm{~Hz}$ yang masuk dalam rentang 300 s.d $1600 \mathrm{~Hz}$ yang dimodulasikan. Hasil ini sesuai dengan spesifikasi penerbangan sipil [1]. Selain itu, penerima sinyal ELT ini mempunyai sensitifitas penerimaan $-40,35 \mathrm{~dB}$ dan selektifitas frekuensi 121,330 s.d 121,617 MHz yang lebih baik, rangkaian sederhana, memerlukan lebih sedikit divais $\mathrm{RF}$, menggunakan sumber tenaga dari baterai, dan portable atau dapat dijinjing karena mempunyai dimensi kurang dari 10 $\mathrm{cm} \times 15 \mathrm{~cm}$ pada satu le mbar PCB. Perbandingan antara hasil penelitian ini dengan penelitian lain yang sudah dilakukan ditunjukkan pada Tabel II.

Dari Tabel II, dapat dilihat bahwa penelitian ini menghasilkan luaran yang lebih baik. Hasil penelitian ini selanjutnya dapat diimplementasikan di penerbangan sipil pada perangkat penerima sinyal ELT dan diintegrasikan dengan perangkat RDF untuk penggunaan oleh petugas SAR pada pencarian lokasi pesawat terbang yang mengalami kecelakaan.

TABel II. Perbandingan antara Hasil Penelitian dengan Penelitian Lain yang Sudah Dilakukan

\begin{tabular}{|c|c|c|c|}
\hline Spesifikasi & Hasil Penelitian ini & $\begin{array}{c}\text { Penelitian Lain yang Sudah } \\
\text { Dilakukan }\end{array}$ & Keterangan Hasil Penelitian ini \\
\hline $\begin{array}{l}\text { Siny al ELT: } \\
\text {-frekuensi } \\
\text {-siny al audio }\end{array}$ & $\begin{array}{l}121,498 \mathrm{MHz} \\
337,6 \mathrm{~Hz}\end{array}$ & $\begin{array}{l}\text { Hasil [1]: } \\
121,5 \mathrm{MHz} \pm 6 \mathrm{kHz} \\
300 \text { s.d } 1600 \mathrm{~Hz}\end{array}$ & Sudah sesuai spesifikasi \\
\hline $\begin{array}{l}\text { Sensitifitas penerimaan } \\
\text { Selektifitas penerimaan } \\
\text { Sinyal audio }\end{array}$ & $\begin{array}{l}-40,35 \mathrm{~dB} \\
121,330 \text { s.d } 121,617 \mathrm{MHz} \\
337,6 \mathrm{~Hz} \\
\text { terdengar }\end{array}$ & $\begin{array}{l}\text { Hasil Vektor-Finder Type VF-121 ELT } \\
\text { Stalker produk dari National RF Inc.: } \\
-10 \mathrm{~dB} \\
118 \mathrm{s.d} 130 \mathrm{MHz} \\
\text { - } \\
\text { "suara bip" }\end{array}$ & $\begin{array}{l}\text { Lebih sensitif dan selektif mendekati } \\
\text { range sinyal ELT }\end{array}$ \\
\hline Frekuensi kerja & $121,5 \mathrm{MHz}$ & Hasil [12]-[15]: $406 \mathrm{MHz}$ & $\begin{array}{l}\text { 121,5 MHz mempuny ai jangkauan } \\
\text { lebih jauh tanpaLoS y ang clear }\end{array}$ \\
\hline \multirow{3}{*}{$\begin{array}{l}\text { Metode penerimaan } \\
\text { dan deteksi siny al ELT }\end{array}$} & \multirow[t]{3}{*}{ direct receiver } & Hasil [8]: direct RF sampling & Sudah berhasil realisasi. \\
\hline & & Hasil [9]-[18]: Super heterodyning & $\begin{array}{l}\text { Lebih sederhana, signifikan } \\
\text { mengurangi divais RF y ang } \\
\text { digunakan. }\end{array}$ \\
\hline & & $\begin{array}{l}\text { Hasil [16]-[18]: AL pasif, PL, dan } \\
\text { SARs, terpasang di pesawat terbang }\end{array}$ & $\begin{array}{l}\text { Portable mempuny ai dimensi kurang } \\
\text { dari } 10 \mathrm{~cm} \times 15 \mathrm{~cm}\end{array}$ \\
\hline Luaran & Penerima siny al ELT & $\begin{array}{l}\text { Hasil [7], [10]-[15]: Konsep dan desain } \\
\text { pengembangan penerima siny al ELT }\end{array}$ & $\begin{array}{l}\text { Sudah terealisasi dalam bentuk } \\
\text { rangkaian }\end{array}$ \\
\hline
\end{tabular}




\section{PENUTUP}

Penelitian ini telah berhasil merealisasikan penerima sinyal ELT dengan metode direct receiver yang dapat menerima sinyal ELT pada rentang frekuensi 121,494 s.d $121,506 \mathrm{MHz}$ sesuai spesifikasi untuk penerbangan sipil, ditunjukkan oleh adanya sinyal audio pada frekuensi $337,6 \mathrm{~Hz}$ di keluaran loudspeaker. Penelitian selanjutnya adalah mengintegrasikan penerima sinyal ELT dengan perangkat RDF yang sesuai.

\section{REFERENSI}

[1] R. J. Wallace and T. P. Hubbard, "Effect of $406 \mathrm{MHz}$ ELTs and COSPAS SARSAT Cessation of $121.5 \mathrm{MHz}$ ELT Monitoring on Search and Rescue Duration for General Aviation Aircraft Accidents in the Contiguous United States," Intemational Journal of Aviation, Aeronautics, and Aerospace, vol. 1, no. 2, pp. 1-16, 2014.

[2] Rustamaji, K. Sawitri, and R. H. Sitepu, "Pembangkit Sinyal ELT pada Frekuensi 121,5 MHz," Jumal Teknik Elektro, vol. 11, no. 1, pp. 9-15, 2019. https://doi.org/10.15294/jte.v1 1i1.19201.

[3] Transport Canada Aeronautical Information Manual (TCAIM): SAR Search and rescue (SAR), Transport Canada, October 10,2019.

[4] T. Sherman, J. Tellez, T. Cady, J. Herrera, H. Haideri, J. Lopez, M. Caudle, S. Bhandari, and D. Tang, "Cooperative search and rescue using autonomous unmanned aerial vehicles," in 2018 AIAA Information Systems-AIAA Infotech@ Aerospace, 2018, p. 1490. Published Online: 7 Jan 2018. https://doi.org/10.2514/6.201 8-1490.

[5] M. Raut, and C. Kendurkar, "Enhancements and alternatives proposed for emergency homing devices," Intemational Journal of Scientific and Research Publications, vol. 9, Issue 8, pp. 92-96, 2019. https://doi.org/10.29322/IJSRP.9.08.2019.p9216.

[6] V. K. Shah, H. J. Patel, and U. N. Jani, "Economical automatic deployable emergency locator transmitter system," in 2017 Intemational conference of Electronics, Communication and Aerospace Technology (ICECA), 2017, vol. 1, pp. 267-270. Date Added to IEEE Xplore: Dec. 18, 2017.

[7] L. Peters, and C. Bil, "Designing an automatic beacon ejection system for aircraft," in 16th AIAA Aviation Technology, Integration, and Operations Conference, 2016, p. 3918. Published Online: 10 Jun 2016. https://doi.org/10.2514/6.2016-3918.

[8] A. Q. Nguyen, A. Amrhar, A. A. Kisomi, X. Fang, and R. Jr. Landry, "In-flight performance analysis of direct RF sampling architecture applied to VHF band avionics," in 2018 IEEE Aerospace Conference, 2018, pp. 1-20. Date Added to IEEE Xplore: Jun. 28, 2018.

[9] M. Rice, G. Lechner, J. Zhang, and J. Zhang, "Results from australian trials of UHF distress beacons over MEO satellites," in 33rd AIAA
Intemational Communications Satellite Systems Conference and Exhibition, 2015, p. 4350. Published Online: 3 Sep 2015. https://doi.org/10.2514/6.2015-4350.

[10] D. Delcuvellerie, "Tracking of aircraft in distress using the cospassarsat system," in 2018 SpaceOps Conference, 2018, p. 2343. Published Online: 25 May 2018. https://doi.org/10.2514/6.2018-2343.

[11] B. A. Kalaria, C. G. Nayak, and N. K. Shrivastava, "Designing a web based module for SAR to ensure data security using JAVA," Intemational Joumal of Computer Science and Mobile Computing, vol. 3, no. 4, pp. 297-306, 2014.

[12] B. A. Srihen, J. P. Yonnet, and M. Benslama, "Design and realization an ELT beacon and decoders of frames $406 \mathrm{MHz}$," in International Conference (IEEE) on Engineering \& MIS (ICEMIS), 2017, pp. 1-6. https://doi.org/10.1 109/ICEMIS.2017.8272967.

[13] B. A. Srihen, J. P. Yonnet, and M. Benslama, "Closed Approach of a Decoder Mobile for the $406 \mathrm{MHz}$ Distress Beacon," Advances in Science, Technology and Engineering Systems Joumal, vol. 3, no. 6, pp. 243-246, 2018

[14] J. M. M. Heredia, Z. Garcia, and J. L. M. Jimenez, "Development of an emergency radio beacon for small unmanned aerial vehicles," IEEE Access, vol. 6, pp. 21570-21581, 2018.

[15] A. Naimurrokhman, Kusnandar, U. Komarudin, A. Daelami, A. G. Suryanto, and A. Munir, "Development of GPS transceiver for quadcopter-based emergency locat or beacon," in 2019 IEEE 5th Intemational Conference on Wireless and Telematics (ICWT), 2019, pp. 1-4. Date Added to IEEE Xplore: Feb. 3, 2020.

[16] Y. Chervoniak, R. Sinitsyn, F. Yanovsky, V. Makarenko, V. Tokarev, and O. Zaporozhets, "Algorithm of passive acoustic locator data processing for flying vehicle detection and tracking." in 2017 IEEE Microwaves, Radar and Remote Sensing Symposium (MRRS), 2017, pp. 43-48. Date Added to IEEE Xplore: Oct. 19, 2017.

[17] L. Arena, and D. Orlando, "Passive location developments in Elettronica SpA: System applications," in 2014 Tyrrhenian Intemational Workshop on Digital Communications-Enhanced Surveillance of Aircraft and Vehicles (TIWDC/ESAV), 2014, pp. 130134. Date Added to IEEEX Xlore: Nov. 6, 2014.

[18] Y. Zhang, B. P. Wang, Y. Fang, and Z. X. Song, "SAR observation error estimation based on maximum relative projection matching." Hindawi International Joumal of Antennas and Propagation, vol. 2020, 2020. https://doi.org/10.1155/2020/3517834.

[19] K. Sawitri, Rustamaji, and A. Adhari, "Osilat or 121,5 MHz pada ELT Menggunakan VCO MCl648," Transmisi, vol. 22, no. 1, pp. 30-37, 2020. https://doi.org/10.14710/transmisi.22.1.30-37.

[20] Rustamaji, K. Sawitri, and G. Fuady, "Radio Direction Finder pada HF Band sebagai Elemen dari Passive Radar," Elkha, vol. 11, no. 2, pp. 107-114,2019. https://doi.org/10.26418/elkha.v11 i2.34733.

[21] Rustamaji, Elektronika Komunikasi, Bandung: Penerbit Itenas, 2017.

[22] R. F. Coughlin, F. F. Driscoll, Operational Amplifiers and Linear Integrated Circuits, London: Prentice-Hall International, 2000. 